\title{
Analysis on Development Characteristics of Chinese New Retail Enterprises under the Internet Plus
}

\author{
Mingxiao Zhao \\ Industrial and Commercial Management Department, Dalian Vocational and Technical College \\ 116035, China
}

Keywords: new retail; development; characteristics

\begin{abstract}
New retail is the theme of the development of China's retail industry. Driven by the Internet technology, new retail redefines "people, goods, and fields". Experience, interaction, quality, and speed have become their main innovations. Iterative change, compliance with demand development, resource integration promotion, and empowerment organization management are the main features of development.
\end{abstract}

The accelerated development of the Internet has made the social economy rapidly transition from the era of industrial civilization to the era of intelligent civilization. The two-wheel drive of technological innovation and demand change has subverted the traditional retail model. Big data, cloud computing, the Internet, the Internet of Things, and artificial intelligence have become the source of power for change and development of new retail enterprises.

\section{Change and development in iteration is the trend of new retail enterprises}

Traditional retail enterprises have experienced four revolutions. The background of change is the change in production methods that leads to changes in consumption power and consumer demand. Through in-depth analysis of retail models, managers systematically design the overall design, and then through demonstration experiments, and then launch each time. Retail transformation model.

In the new retail era, under the high-speed "link" of the Internet, the social environment has not allowed "prudent start" and "systematic structure". Consumers who like early adopters and pursue speed are not willing to adapt to "stable change" and "thinking after "Business". The working method under the Internet is to quickly iterate, and the spelling is "acceleration": look at the general direction, quickly deploy, and work closely with consumers, continuously feedback and collect user opinions, and quickly iterate.

\subsection{Actively seek change and lead change.}

The essence of the retail industry is to meet the needs of consumers, and each generation of change has also changed because of the needs of "consumers". The change in the new retail era is not only to respond to changes in demand, but to drive demand and meet the potential needs of "consumers" who are numb by habits.

New retails from the initial "shopping artifacts", later "7FRESH", "Su Xiansheng" and other new 
retail formats, as well as 2017 "Tmall" and brand-name "customized" consumption, these innovative models are the initiative of retail enterprises Change and lead the representatives of consumption.

\subsection{Perfect in practice, upgrade in change}

Iterative change changes the traditional "first analysis of requirements, then overall and detailed design, and then the engineering ideas of development and testing", replaced by the idea of biological growth and metabolism, with a simple prototype to minimize the feasibility of products ( MVP), rapid iteration, continuous correction of products, and finally adapt to market demand 2 .

The speed of the Internet era makes "development and change" to be designed by the side, and agile development and iterative iteration can adapt to the rapid development of consumer demand, so that it can not be left behind in a highly competitive market. With the vision, we will immediately reach a consensus in internal communication, learn by doing, repeatedly iterate and perfect in practice, and complete the upgrade task in the process of change.

\subsection{Consumer participation, more precise change}

The biggest advantage of iterative change is "through market testing, consumer feedback participation, making changes more in line with consumer demand, and responding to market changes accurately".

If a certain marketing model takes a while to complete the design, but if you take out the "blank" products in a short period of time and put them on the market, there will be many problems. The early adopters will participate in the "new marketing model". Many more detailed revisions will be made through comments and customer feedback, and there will be many "sparks" in the process of "employees" in the service of customers. In this way, the designer knows how far he is from the customer's needs, so that according to the further improvement of the consumer feedback, a more perfect "model" can be adopted, so that the new marketing model of change can gradually approach the customer in function and service. Requirements.

\section{Complying with the emotional needs of consumers is the origin of the development of new retail enterprises}

I don't know if the Internet era has created today's consumers, or today's consumers have brought the Internet economy to the extreme. In short, consumers are more and more like "netizens", and residents with the same attributes as the Internet. Consumer demand has obvious characteristics of the times in the new retail era. Consumers are victorious but lack patience, focus on self, emphasize individuality and make a difference, like new things, have strong tastes of taste, pay attention to consumer experience and feelings; today's consumers are more and more pragmatic, do not pursue ownership, but seek to enjoy However, they value the participation and the right to know in consumption, and they prefer open and interactive consumption.

The essence of new retail is also the data-driven pan-retail style centered on the consumer experience. 3 The application of big data technology makes the consumer demand insight more accurate and easier. The head of the new retail knows "who touched the inner needs of consumers" and whoever gets the economic growth point.

\subsection{The "new economy" that is consistent with new consumer demand is popular.}

In the Internet era, the "sharing" economy, such as "shared bicycles" and "dividing", has become the main force in China's new economic transformation. The emergence of the sharing economy in 
the field of travel has also led to the development of "part-time economy". A group of young people have become "freelancers". They may still hold high salaries in a company building during the day, and may be "on the way out of work". Sharing drivers, the weekend may also be "self-media writers" and occasionally appear in the "express team." The development of micro-business is a new economic effect of "friend circle", and consumers consume because of trust, economy, convenience and human feelings.

The new retail is well versed in customer rules. Mastering customer channels is still the foundation of marketing success. Through "pragmatic", "materialized" and "all-channel" docking consumers, consumers are always online.

\subsection{The "all-channel operation" consistent with the needs of new consumers.}

The "all-channel operation" model is the enlightenment stage of the "new retail" revolution, when consumers have created their own "offline experience, online ordering" consumption. The new retail has built a new online and offline shopping scene supported by big data analysis through digitization of products, digitization of members, and digitization of stores, which has enhanced the shopping experience of consumers in solemnify-channel and mufti-scene.

The typical representative stores of the new retail are "super species" and "box horse fresh students". Their organizational form is not "commodity-centered" in the traditional sense, but "consumer demand" as the core, building consumer online + offline , catering + retail, sales + experience, quality + life, life scene-style all-round texture experience, cut the consumer mind.

\subsection{The "customized" consumption pattern compatible with the needs of new consumers}

In 2017, the "Tmall" shopping festival took the lead in opening a customized consumption method. Tmall launched a customized Wufangzhai scorpion at the Dragon Boat Festival. Consumers placed orders on the Tmall platform and customized the taste and style of the scorpion according to personal preferences. The degree of penalization depends entirely on consumer preferences. A variety of tweezers are tailored to the needs of consumers, which completely reshapes the manufacturing process of traditional foods and achieves non-standard customization of standard products.

3. The integration of multi-access resources has become the main driving force for the development of new retail industry

The development of new retail is no longer a matter for retailers. Its social attributes have attracted the participation of mufti-party capital, mufti-party technology and mufti-party forces. The integration of various resources has contributed to the retail industry.

\subsection{Online and offline unbounded integration}

The new retail revolution is the deep integration of traditional offline retail and online retail. The essence of the new retail is "online + offline + smart logistics", is a fusion economy.

Ali-baba is the largest Internet company on the Internet. It has opened a new retail format for offline "box horse fresh life". Since then, the Ali line has been staking, and has successively invested in physical retail enterprises such as Sining, Sanjiang Shopping and Yintai. In 2017, it joined the Bailian Group. The Group and Gaoxin Retail achieved perfect online and offline integration; offline retail giants "Wal-Mart, Yonghui" have touched the net and cooperated with Jingdong's e-commerce to make the offline economy profitable. 


\subsection{Cross-border integration, capital and retail industry marriage}

The new retail dividends have allowed all the capital to invest, cross-border integration, and marriage with retail companies, so that the retail economy that is not bad money is flying higher. In 2016 and 2017, it was the year of convenience store format. Unmanned convenience stores, unattended shelves, new convenience stores, and modified convenience stores were favored by many investors. Alibaba's former vice president Lu Guangkai was founded in August 2017. "Nasty Convenience" won the financing of 100 million angels, and the former general manager, Li Lijun, founded the "Gao Xiaomei" convenience store, which was sought after by many star investors...

\subsection{Technology-driven, network technology and retail art are the perfect combination}

The reform and development of new retail does not deviate from the "retail of retail", it is always the display of retail art, "display art" allows consumers to see different goods, "promotional strategy" makes "double eleven" become a feast for all people shopping. "Retail Art" plugs in the wings of "network technology" to make new retail "good looking", "fun" and "good money".

The "New Retail Experience Pavilion" opened by "Tmall" shows a series of technology-driven new retail experiences such as Sky Eye AR Scan, Virtual Mirror, Virtual Fitting Room and Multi-screen Interactive. Behind the "black technology" is the interactive customization of "Tmall" for "smart stores", which has formed a complete set of business service rules and technical capabilities. This is the driving force behind Tmall's continued empowerment on the new retail road. ${ }^{6}$.

\section{Empowered organizations invigorate the development of new retail enterprises}

The development of the retail industry is inseparable from the support of retailers. It is the courage of retailers to unite, innovative thinking and constant revolution to bring new retail in China today. Shi Jie, vice president of the new retail human resources of Alibaba Group, said at the 2018 China Chain Enterprise Human Resources Summit: The new retail transformation begins with the system and becomes organizational change. The retail industry embraces a new era. The core is to restructure the relationship between organizations and people, stimulate organizational vitality, innovate talent mechanisms, and enhance talent effectiveness to keep up with the times.

Zeng Ming, vice president of Alibaba Group, believes that "the most important function of the future organization is empowerment": employees in the empowerment organization structure continue to grow at work, get exercise and growth in their work; leadership is the most important in the empowerment organization structure. The job is to support the subordinates to succeed, to give employees enough room for growth, necessary support and guidance, and certain resources to ensure that all employees benefit and grow at work.

\subsection{Amoeba operates, allowing each small molecule to face the market directly}

Amoeba management is the business model of "full participation" management proposed by Mr. Inamori and $\mathrm{Mr}$. Fu, the "Management of Japan". Under this model, the company divides the organization into small groups, and each small group directly contacts the market., conduct independent accounting and cultivate market awareness, and form a corporate model of full staff management.

Under the Amoeba business model, the company has been injected with unprecedented vitality and creativity. The employee's sense of ownership and huge potential for work have been greatly developed, and the "management management" of the boss has become a "management person". 


\subsection{Partner model, let each practitioner share the benefits of change}

The Amoeba business model has been maximized by the retail star "Yonghui" and is the first partner model in the retail industry. "Yonghui Partner" has only the right to distribute dividends and does not enjoy the company's equity and stocks. Its essence is to encourage grassroots employees to redistribute income between headquarters and small teams.

The change of the partnership model has greatly enhanced the sense of responsibility of the "owners" of the front line employees in the retail industry. The employees changed the working attitude of "when one day is a day", binding the interests of "employees" and "enterprises", caring, paying attention to Improving corporate performance has become the internal driving force for employees' work, not only retaining people but also retaining their hearts.

\subsection{Platform organization, so that everyone can achieve self-improvement in the realization of organizational goals}

The platform organization is a new organizational transformation with Internet genes. Its typical four characteristics are a large number of independent small front ends, large-scale support platforms, mufti-ecosystems and bottom-up internal entrepreneurship.

The platform organization is the optimization of the organizational structure of the Internet economy to deal with the "quickly changing market". In the platform organization, the organizational structure is removed from the middle layer, and free teams are established according to business needs. Each business team is like a "growth platform" and directly faces The market solves problems and achieves a rapid response to the market. The platform organization is the manager's response to the organizational structure optimization of "personality after the 90s." This platform organization is in line with the desire of young people to grow up independently and independently. The platform is the testing ground and decision-making place for young people. They can pass in a short period of time. The "platform position" has achieved the realization of their personal career goals, injecting new kinetic energy into the enterprise.

\subsection{Ecological organization, making customers an important fan economy}

The biggest shortcoming of the traditional organization is that it is far from the customer, and it is not able to quickly capture the changes of consumers, and the interaction with consumers is weak. The characteristics of the ecological organization will extend the tentacles to the market terminals, let the organizational system and product innovations close to the consumers, and understand the changes in consumer demand and product feedback, and quickly reflect. Consumers have also become part of the organization. Consumers are involved in corporate $\mathrm{R} \& \mathrm{D}$, innovation and change. Customization, sovereignty, word of mouth and socialist are the characteristics of new retail marketing.

The future has come, China's new retailers have taken the lead in opening up the innovative development model, constantly creating new business miracles with a spirit of perseverance, integrating into the new era, active docking, link change, change and development, matching innovation, passionate investment, and have come out A new era of retail development with Chinese characteristics.

\section{References}

[1] Yonghui member store is really terrible is the "iteration" speed, http://www.sohu.com/a/132453179_180092, Sohu.com financial channel

[2] Tian Junguo. Empowering leadership. Zhejiang People's Publishing House. (2017).7(28) 
[3] New Retail Research Report. Ali Research Institute. http://www.aliresearch.com/

[4] The Circulation Industry Promotion Center of the Ministry of Commerce released the report "Into the New Era of Retail-In-depth Interpretation of New Retail". http://www.mofcom.gov.cn/. Ministry of Commerce of the People's Republic of China.2017.9

[5] In the new retail era, do you want to "squid" or "hegemony"? China Times Network http://www.chinatimes.net.cn/article/70932.html 2017.09.21

[6] Tmall's new retail continues to deepen the land of "wisdom store" into the original driving force, http://finance.jrj.com.cn/tech/2017/07/06083622705034.shtml Technology Channel-Financial Circle, 2017.07.06

[7] Boston Consulting: Platforming organizations are expected to lead the future organizational changes, Xinhuanet http://www.xinhuanet.com/fortune/2016-10/17/c_1119735161.htm, 2016.10.17 